\title{
Weed Suppression and Component Crops Response in Maize/Pumpkin Intercropping Systems in Zimbabwe
}

\author{
Mandumbu Ronald ${ }^{1} \&$ Karavina Charles ${ }^{1}$ \\ ${ }^{1}$ Department of Crop Science, Bindura University of Science Education, Private Bag 1020, Bindura, Zimbabwe \\ Corrrespondence: Mandumbu Ronald, Department of Crop Science, Bindura University of Science Education, \\ Private Bag 1020, Bindura, Zimbabwe. Tel: 263-772-919-821. E-mail: rmandumbu@gmail.com
}

Received: January 20, 2012 Accepted: February 10, 2012 Online Published: June 6, 2012

doi:10.5539/jas.v4n7p231

URL: http://dx.doi.org/10.5539/jas.v4n7p231

\begin{abstract}
Intercropping is a common practice in the smallholder sector of Zimbabwe with potential contribution to weed management. The proper combination of plant population, composition of the component species and frequency of weeding which lead to weed suppression are still unknown and that prompted this investigation. The experiment was set up as a factorial experiment in a randomised complete block design with three factors: cropping systems (sole maize, sole pumpkins and maize/pumpkin intercrop), weeding regimes (weeding at 3 weeks after planting (WAP) and at 3 and 8 WAP) and pumpkin population (16.5\% and 33\%) of maize population. Results showed no significant effect of cropping system, pumpkin population and weeding regime on maize yield, pumpkin yield, pumpkin leaf number and weed density. Weed biomass was significantly higher $(\mathrm{P}=0.000)$ at weeding regimes of 3 WAP than at 3 and 8 WAP. Pumpkin population of $16.5 \%$ had higher weed biomass compared to $33 \%$. Themaize/pumpkin intercrop had significantly $(\mathrm{P}=0.002)$ lower weed biomass compared to sole crops. There were significant interactions of weeding regime and pumpkin population and cropping system and pumpkin population $(\mathrm{P}=0.035)$. The results indicate that intercrops with 33\% pumpkin population and weeded at 3 and 8 WAP are superior in terms of weed biomass suppression. Intercropping done at correct crop combination and weeding at the right time therefore shifts crop-weed competition in favour of the crop as it reduces dry matter accumulation of the weeds without affecting yield of component crops. Intercropping can therefore be used as a component in integrated weed management in the smallholder sector.
\end{abstract}

Keywords: intercropping, weed management, cropping system, plant population, weed biomass, smallholder farmers

\section{Introduction}

Intercropping is the growing of two or more crops on the same piece of land in the same growing season (Andrews \& Kassam, 1975). It is the commonest type of cropping system in Africa, Asia and Latin America where more than $80 \%$ of the farmers practice it (Edge, 1990). The rationale of growing two or more crops together with diverse growth habits and/or durations is for efficient exploitation of nutrients and water from different soil layers and more efficient light interception compared to a single crop. Increasing the complexity of a cropping system by inter-planting species of different growth forms, phenologies and physiologies can create different patterns of resource consumption by crops and can present a very different pattern of resource availability to weeds (Liebman, 1988).

When crops are grown together, depending on the combinations, they can interact co-operately to the benefit of the farmer (Hoyt \& Coolman, 1993). In southern Africa, the most common cropping combinations are staple crops (maize, sorghum and millets) with cucurbits and legumes (Mariga, 1990). Studies done in India (Rao \& Shetty, 1976; Janiya \& Moody, 1984) revealed that intercropping reduces the number of cultivations required for acceptable crop yields: a situation which reflects increased competitive domination of weeds by intercrops. In intercrops of peas (Pisum sativumL.) and barley (Hodeumvulgare L.), Hauggaard-Nielsen et al. (2001) found that there competitive ability towards weeds as compared to sole crops.

In Zimbabwe, Mashingaidze (2004) reported that manual weeding is the main weed control method used in the smallholder sector. Chivinge (1990) described the method as slow, labour intensive, cumbersome and inefficient. 
This increases the drudgery that is associated with crop production in Zimbabwe's smallholder sector which does not match yields obtained because other factors such as timeliness in weeding are not observed. There is therefore need for research to come up with appropriate cropping systems which are weed suppressive of which intercropping is a candidate.

Despite the fact that intercropping is a common practice in Zimbabwe's smallholder sector, research still needs to come up with appropriate population combinations that achieve weed suppression. The response of the minor crop in the intercrop is usually ignored in most intercrop studies. This research was designed to answer the following questions: does intercropping with different pumpkin population reduce weed germination and resource capture? What is the response of pumpkins under shaded conditions of the intercrop?

\section{Materials and Methods}

\subsection{Research Site}

The trial was conducted at the University of Zimbabwe Farm in natural region IIa (altitude and latitude) on the red fersialitic clay soils. Average summer temperature is $25^{\circ} \mathrm{C}$ and the average rainfall for the site is $730 \mathrm{~mm}$. The $\mathrm{pH}$ of the soils was 5.7 and clay content is $30 \%$.

\subsection{Experimental Design}

The trial was set up as a factorial experiment in a randomised complete block design with three replications. The three factors tested in the experiment were cropping system, weeding regimes and pumpkin population. Cropping systems were sole maize, maize pumpkin intercrop and sole pumpkin. Weeding regime had two levels: weeding at three weeks after planting (WAP) and weeding at three and eight WAP. Planting population had two levels: 12400 plants $/$ ha and 6200 plants $/$ ha. The gross plots were $6 \mathrm{~m} * 8.1 \mathrm{~m}$ and for maize, the net plots were $6 \mathrm{~m} * 3.6 \mathrm{~m}$.

\subsection{Agronomic Practices}

The land was disc-ploughed and harrowed to fine tilth. Maizefert (8\% N: $\left.14 \% \mathrm{P}_{2} \mathrm{O}_{5}: 7 \% \mathrm{~K}_{2} \mathrm{O}: 8.5 \% \mathrm{~S}\right)$ was applied at $300 \mathrm{~kg} / \mathrm{ha}$ as a basal dressing. Ammonium nitrate $(35 \% \mathrm{~N})$ was applied as top dressing at $8 \mathrm{WAP}$ at $200 \mathrm{~kg} / \mathrm{ha}$. The short season maize variety PAN 87 was inter-row inter-planted with commercial pumpkin variety Flat White Boer. Pumpkins were established at a spacing of $1.8 \mathrm{~m} * 0.45 \mathrm{~m}$ and half the plots were thinned to a spacing of $1.8^{*} 0.9 \mathrm{~m}$ at $4 \mathrm{WAP}$ either as a sole crop or intra-row inter-planted with maize to give a pumpkin population of 12400 plants/ha which is equivalent to $33 \%$ of the maize population. In half the plots, pumpkin population was reduced to $6200 \mathrm{plants} / \mathrm{ha}$, which is $16.5 \%$ of the maize density at $8 \mathrm{WAP}$. Maize was planted at $0.9 * 0.3 \mathrm{~m}$ to give a density of 37037 plants per hectare. Two seeds were planted at each planting stations and plants were thinned to one plant per station at one week after emergence.

\subsection{Data Collection and Analysis}

Pumpkin leaf number, vine length and branch number were measured on the main vine on three plants per plot. Vine length was measured using a tape measure. Branch number was found by counting the number of branches on the main vine on three plants per plot at 12 WAP. Weed density and biomass were determined when a $1 \mathrm{~m} * 1 \mathrm{~m}$ quadrant was randomly thrown into each net plot and weeds were counted by species at $15 \mathrm{WAP}$. The weeds were cut at ground level; oven dried at $70^{\circ} \mathrm{C}$ for 72 hours and weighed using a sensitive balance. Maize grain yield was measured at physiological maturity at $25 \mathrm{WAP}$ at $12.5 \%$ moisture content. Pumpkin yield was determined from the gross plot and fruits were weighed and counted. Weed density data was square root transformed before analysis. Data was analysed using Genstat version 6 and where there were significant differences, the means were separated using the least significant difference (LSD) at 0.05 probability level.

\section{Results}

\subsection{Weed Density and Biomass}

Weed density was not significantly $(\mathrm{P}>0.05)$ affected by weeding regime, cropping system and pumpkin density (Table 1). A significantly higher weed biomass $(\mathrm{P}<0.05)$ was recorded at lower pumpkin population $(16.5 \%)$ than the higher density of $33 \%$ of the maize density. The increase in weeding intensity from weeding at 3 WAP to weeding at 3 and 8 WAP significantly $(\mathrm{P}<0.05)$ reduced weed biomass (Table 1$)$ at the pumpkin population of 12400 plants per hectare. Intercrop had the significantly lower $(\mathrm{p}=0.002)$ weed biomass compared to sole maize and sole pumpkins (Table 1). 
Table 1. Effect of cropping system, pumpkin population and weeding regime on weed density and biomass

\begin{tabular}{lcc}
\hline Weeding regime & Weed biomass $(\mathbf{g})$ & Weed density(plants $\left./ \mathbf{m}^{\mathbf{2}}\right)$ \\
\hline 3 WAP & $131.38 \mathrm{~b}$ & 7.74 \\
3 \& 8 WAP & $22.12 \mathrm{a}$ & 6.4 \\
P-value & 0.000 & 0.074 \\
\hline Pumpkin population & & \\
$16.5 \%$ & $101.62 \mathrm{~b}$ & 6.4 \\
$33 \%$ & $51.88 \mathrm{a}$ & 7.74 \\
LSD & 26.99 & $\mathrm{NS}$ \\
P-value & 0.017 & 0.341 \\
\hline Cropping system & & \\
Sole maize & $87.33 \mathrm{~b}$ & 7.23 \\
Sole pumpkins & $111.07 \mathrm{~b}$ & 7.66 \\
Intercrop & $42.42 \mathrm{a}$ & 6.48 \\
LSD & 36.6 & $\mathrm{NS}$ \\
P-value & 0.002 & 0.27 \\
\hline
\end{tabular}

NS: Not Significant. Means followed by different letters in a column under a subheading are significantly different.

There was no significant interaction of the treatment factors to weed density. A significant interaction ( $\mathrm{P}=0.039)$ of pumpkin population and weeding regimes revealed a higher biomass where there is only one weeding with $16.5 \%$ pumpkin population (Figure 1).

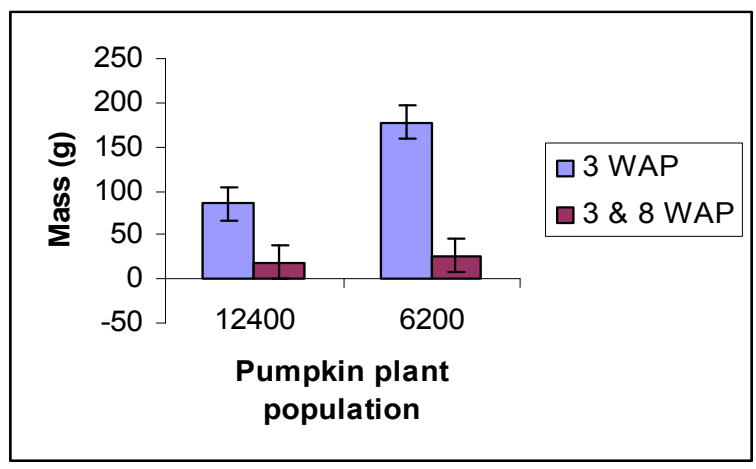

Figure 1. Plant population and weeding regime effects on weed biomass

A significant interaction $(\mathrm{P}=0.035)$ of cropping system and pumpkin population on weed biomass revealed that sole pumpkins and pumpkin population of 6200 plants resulted in higher weed biomass (Figure 2).

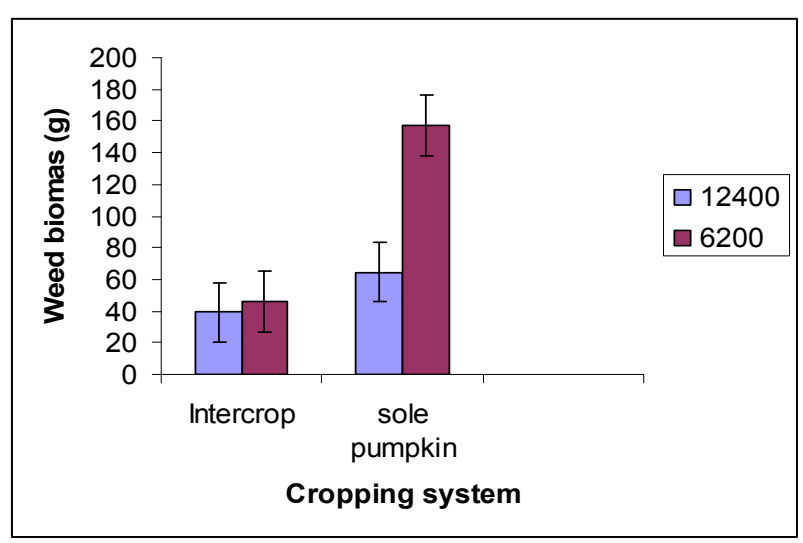

Figure 2. Interaction effects of cropping system and pumpkin population on weed biomass 


\subsection{Pumpkin Branching, Vine Length and Leaf Number}

Pumpkin vine length and leaf numbers were not significantly affected by all treatment factors (Table 2). There were no significant interactions between and among treatment factors. However pumpkin branch number was significantly higher $(\mathrm{P}=0.000)$ in the monocrop compared to the intercrop (Table 2$)$.

Table 2. Effect of weeding regime, plant population and cropping system on pumpkins

\begin{tabular}{llll}
\hline Treatments & Vine length $(\mathbf{m})$ & Leaf number & Branch number \\
\hline Weeding regime & & & \\
3 WAP & 2.5 & 18.71 & 6 \\
3 \& 8 WAP & 2.37 & 18.44 & 5.58 \\
LSD $(0.05)$ & $\mathrm{NS}$ & $\mathrm{NS}$ & $\mathrm{NS}$ \\
\hline Pumpkin population & & & \\
$16.5 \%$ & 2.47 & 18.34 & 5.58 \\
$33 \%$ & 18.8 & 6 \\
LSD $(0.05)$ & $\mathrm{NS}$ & $\mathrm{NS}$ & $\mathrm{NS}$ \\
\hline Cropping system & & & \\
Sole Pumpkin & 2.44 & 18.92 & $8.41 \mathrm{a}$ \\
Intercrop & 2.43 & 18.23 & $3.17 \mathrm{~b}$ \\
LSD $(0.05)$ & $\mathrm{NS}$ & $\mathrm{NS}$ & 0.918 \\
CV $(\%)$ & 24 & 34 & 29 \\
& & & \\
\hline
\end{tabular}

Means followed by different letters in the same row are significantly different

\subsection{Maize Grain Yield and Pumpkin Fruit Yield}

Maize and pumpkin yield was not affected by all treatment factors (Table 3). There was no significant interaction between and among treatment factors. However pumpkin yield was generally low because there was a lot of rainfall and the pumpkins were severely affected by powdery mildews.

Table 3. Effect of cropping system, plant population and weeding regime on maize yield and pumpkin fruit yield

\begin{tabular}{lll}
\hline Treatments & Maize yield (tons/ha) & Pumpkin yield (tons/ha) \\
\hline Weeding regime & & \\
Weeding at 3 WAP & 3.7 & 0.788 \\
Weeding at 3 \&8 WAP & 3.78 & 0.737 \\
LSD $(0.05)$ & NS & NS \\
Pumpkin Population & & \\
$16.5 \%$ & 3.7 & 0.726 \\
$33 \%$ & 3.28 & 0.799 \\
LSD $(0.05)$ & NS & NS \\
Cropping System & & \\
Sole maize & 4.029 & \\
Sole pumpkins & & 0.794 \\
Intercrop & 3.5 & 0.73 \\
LSD $(0.05)$ & NS & NS \\
\hline
\end{tabular}

\section{Discussion}

Weed numbers were not significantly affected by two weeding regimes, pumpkin population and cropping system. This indicates that neither monocrop nor intercrop had an inherent mechanism of controlling weed germination. This is so because cultivation effects during land preparation and during weeding brings weed seeds to the surface, influences gaseous state of the soil and exposes weed seeds to light. This is in agreement to with Suer and Styerik (1964) who found that weeds receiving as little as 0.5 seconds of direct sunlight during cultivation might be induced to germinate. Weed density was not affected by weeding regimes because every form of soil disturbance stimulates germination from the seed bank. This is supported by Harper, (1990) who reported that by weeding the 
buried seeds are brought from deeper soil layers to the surface hence every weeding is followed by a flush of germinating weeds. Cropping systems (sole crops or intercrop) have no inherent mechanism of controlling weed germination as they can not completely shut out light from reaching the ground.

Intercropping resulted in less harvestable dry matter compared to monocropping. This is in agreement with the findings of Mugabe et al., (1980); Fleck et al., (1984) and Bridgemohan (1989), who found that weed weight in crop mixtures were less than the respective component crop species. Cropping mixture alters light quality and quantity and that reduces the photosynthetic capacity. Shading results in a decrease in incident light which lower photosynthetic rate and decreases the activity of ribulosebiphosphate carboxylase or phosphoenol pyruvate carboxylase and chlorophyll content.Harzel (1973) also found that intercropping suppress weed tillering and so it reduces weed biomass accumulation and seed production capacity. Mugabe et al. (1980) concluded that intercropping is effective in suppressing the growth of already existing weeds which is consistent with the results of this study.

Weeding at 3 WAP had greater weed biomass compared to weeding at 3 and 8 WAP. This illustrates that the increases in number of weeding regimes decreases weed competitiveness. A higher weed biomass in plots with $16.5 \%$ pumpkin population compared to $33 \%$ further supports the effect of leaf density on weed competitiveness. Mugabe et al. (1980) pointed out that crop species, variety and plant population are some aspects of management that have a strong bearing in the shifting of crop/weed balance in favour of the crop. In this study weeding once in sole maize resulted in higher weed biomass compared to weeding once in intercrops. In the intercrop there were no significant differences in weeding at $3 \mathrm{WAP}$ and weeding at 3 and $8 \mathrm{WAP}$. This implies that the second weeding can be replaced by intercropping.

Interaction of cropping systems and pumpkin population on weed biomass reveals that weed biomass was higher in sole pumpkins compared to the intercrop. This indicates the superiority of intercropping in weed suppression compared to sole cropping. These results concur with the findings by Mashingaidze (2004) who reported that intercrops are superior to mono crops when it comes to weed suppression.

Weeding regime significantly affected weed biomass with weeding at 3 WAP having a greater weed biomass compared to weeds weeded at 3 and 8 WAP. This illustrates that the increases in weeding intensity decreases the competitiveness of weeds as the crop will have established and hence outcompetes weeds. A higher weed biomass within plots with $16.5 \%$ pumpkin population compared to $33 \%$ further supports the effect of leaf density and the shading effect. Mugabe et al. (1980) pointed out that crop species; variety and plant population are some aspects of management that have a strong bearing in the shifting of crop weed balance in favour of the crops. The significant interactions of weeding regime and pumpkin population on weed biomass suggest that intercropping can reduces the frequency of weeding.

Pumpkin sole crop had significantly more branches compared to the intercrop. This is in agreement with the findings of Bello et al. (1995) who reported that at $76 \%$ artificial shading branching is reduced. This is because the plant tends to invest more assimilates in leaf area in order to harness the limited incident light (Johnston and Onuweme, 1998). Vine length and leaf number were not affected by all treatment factors. These results are consistent with the findings of Johnston and Onueme (1998) who reported that assimilate does not build new leaves but are used to make more chlorophyll in existing leaves to increase light harvesting. The lack of difference in vine length and leaf number confirms the studies by Soussana et al. (1995) which showed that radiation use efficiency was significantly higher in shaded plant than the dominant crop. Thomlison et al. (1998) showed that the efficiency of biomass production per mole of photons captured by the crop was greater under shade than in full sunlight.

The economic yield of both pumpkins and maize was not significantly affected by all treatment factors and neither was there a significant interaction of the factors. Pumpkins in this study were affected by downy mildew which led to premature damage to foliage. Weeding regime had no effect on maize yield. This could have been caused of the fact that maize was weeded in all plots during the critical period. Li (1960) as quoted in Altieri and Liebman (1988), reported that if weeding is done during the critical period yield may not be affected much by lack of subsequent weeding.

\section{Conclusion}

Intercropping shifted weed/crop competition in favour of the crop as demonstrated by reduction in weed biomass accumulation. Weeding twice at a higher pumpkin population reduces weed competitiveness as measured by reduced dry mater accumulation. Although weed density was not affected by treatment factors intercropping succeeded in reducing weed competitiveness. Intercropping can therefore be used as a weed control tool and as a tool in the broader integrated weed management program without affecting yields of the component crops. 


\section{References}

Andrews, \& Kassam. (1975). The importance of multiple cropping in increasing world food supplies. In multiple cropping, Papendik, R. I; Sanchez, P. A and Triplett, G. B (Eds). American Society of Agronomy.

Bello, A., Owen, M., \& Hitterman-Valenti. (1995). Effect of velvet leaf (Abutilon theophrasti), growth, seed production and dormancy. Weed Technology, 5, 452-455.

Bridgemohan, P. (1989). Intercropping- an eco-physiological approach to integrated weed management. In Eco-physiology of tropical intercropping, Eds: HerveSinoquet and Pablo Cruz, INRA, PARIS.

Chivinge, O. A. (1990). Weed science technological needs of communal areas of Zimbabwe. ZambeziaXV(ii), 133-143.

Edge, O. T. (1990). Relevance of workshop to farming in Eastern and Southern Africa. In research methods for cereal/legume intercropping in eastern and southern Africa. Waddington, S. R; Palmer, A. E. F and Edge, O. $\mathrm{T}$.

Fleck, N. G, Machado, C. M. N., \& de Souza, R. S. (1984). Efficiencia da consorciacao de culturas no controls de plantasdanhinaspersqui. Agropercu Bras, 19(5), 591-598.

Hauggaard-Nielsen, H., Ambus.P., \& Jensen, E. S. (2001). Interspecific competition, N use and interference with weeds in pea barley intercropping. Field crops Research, 70, 101-109. http://dx.doi.org/10.1016/S0378-4290(01)00126-5

Harzel, A. K. (1973). Competitive relationship between maize (Zea mays) and the weed Rottboeliaexaltata. Journal of agric Science.

Harper, J. L. (1990). Population biology of plants. Academic press, New York.

Hoyt, G., \& Coolman, J. (1993). Increasing sustainability by intercropping. Hort Technology, 3(3), 170-176.

Janiya, J. D., \& Moody, K. (1984). Use of the Azolla in transplanted rice. Tropical Pest Management, 30(10), 1-8. http://dx.doi.org/10.1080/09670878409370842

Johnstone, \& Onwueme. (1998). The effect of photosynthetic pigments of planting taro under tannia in agro-systems. Experimental Agriculture, 34(3), 301-312.

Li, M. Y. (1960). An evaluation of the critical period and effects of weed competition on oats and corn. A doctoral dissertation. As quoted in Weed management in agrosystems: Ecological approaches to weed management in agro ecosystems. Editors Manguel, A. Altieri and Matt Liebmann. CRC Press, 198-209.

Liebman, M. (1988). Ecological suppression of weeds in intercropping systems: A review. In EdsAltieri, M. A. and Liebman, M. Weed management in agrosystems: ecological approaches. CRC press.

Mariga, I. K. (1990). Effect of cowpea planting date and density and performance of maize/cowpea intercrop. Zimbabwe Journal of Agric Research, 28, 125-121.

Mashingaidze, A. B. (2004). Improving weed management and crop productivity in maize systems in Zimbabwe. Tropical Resource Management Paper, 57. Wageningen University and Research Centre.

Mugabe, N. R, Sinje, M., \& Sibuga, P. (1980). A study of weed crop competition in intercropping. Symposium on intercropping in semi-arid areas. Morogoro, Tanzania.

Rao, M. R., \& Shetty, S. V. R. (1976). Some biological aspects of intercropping systems on crop weed balance. Indian Journal of Weed Science, 8(1), 32-38.

Sauer, J., \& Strerick, G. (1964). A possible ecological relationship between soil disturbances, light flush and seed germination. Ecology, 884. http://dx.doi.org/10.2307/1934942

Saussana, J. F, Faurie, O., \& Sinoquet, H. (1995). Radiation and nitrogen acquisition and use in simulated grass/clover swards. In Eco-physiology of intercropping (Eds) H Sinoquet and Pablo Cruz.INRA editions, Paris.

Thomlison, H. F, Brook, R. M., \& Wilson, T. D. (1989). Interaction between n'ere and underplanted sorghum in parkland system in Burkina Farso. Experimental Agriculture, 34(1), 45-49. 